\title{
REVIEW
}

\section{Three periods of one and a half decade of ischemic stroke susceptibility gene research: lessons we have learned}

Anita Maasz and Bela Melegh*

\begin{abstract}
Candidate gene association studies, linkage studies and genome-wide association studies have highlighted the role of genetic factors in the development of ischemic stroke. This research started over a decade ago, and can be separated into three major periods of research. In the first wave classic susceptibility markers associated with other diseases (such as the Leiden mutation in Factor $V$ and mutations in the prothrombin and 5,10-methylenetetrahydrofolate reductase (MTHFR) genes) were tested for their role in stroke. These first studies used just a couple of hundred samples or even less. The second and still ongoing period bridges the two other periods of research and has led to a rapid increase in the spectrum of functional variants of genes or genomic regions, discovered primarily in relation to other diseases, tested on larger stroke samples of clinically better stratified patients. Large numbers of these alleles were originally discovered by array-based genome-wide association studies. The third period of research involves the direct array screening of large samples; this approach represents significant progress for research in the field. Research into susceptibility genes for stroke has taught us that careful stratification of patients is critical, that susceptibility alleles are often shared between diseases, and that not all susceptibility factors that associate with clinical traits that are themselves risk factors for stroke (such as increase of triglycerides) necessarily represent susceptibility for stroke. Research so far has been mainly focused on large- and small-vessel associated stroke, and knowledge on other types of stroke, which represent much smaller population samples, is still very scarce. Although some susceptibility allele tests are on the palette of some direct-to-consumer companies, the clinical utility and clinical validity of these test results still do not support their use in clinical practice.
\end{abstract}

\section{Clinical relevance of stroke}

According to the definition of the World Health Organization, stroke is defined as suddenly developing, temporary or, in unfavorable cases, permanent damage to the brain $[1,2]$. It can affect both men and women at any time of life; however, it is more prevalent in men over 45 years of age [3].

The disease can be classified into two subgroups: hemorrhagic stroke, involving leakage of blood, and ischemic stroke, involving blockage of blood flow. Ischemic stroke comprises 80 to $85 \%$ of all stroke cases; 15 to $20 \%$ of the cases are hemorrhagic, which comprise intracerebral and subarachnoid stroke. Ischemic stroke can be the result of various pathophysiological mechanisms,

*Correspondence: bela.melegh@aok.pte.hu

Department of Medical Genetics, University of Pecs, H-7624 Pecs, Szigeti 12, Hungary such as atherothrombosis (75\% of cases) or embolism (25\% of cases), which lead to occlusions in the arteries. However, up to $30 \%$ of ischemic strokes can have other causes, such as systemic hypoperfusion (general decrease in blood circulation).

Acute ischemic stroke has been listed as the third leading cause of mortality after cardiovascular events and malignant tumors $[4,5]$. However, the number of stroke attacks is on the rise owing to demographic changes and inadequate primary or secondary prevention [6]. Donnan et al. [7] regarded stroke as the second most common cause of death after ischemic heart disease worldwide.

The incidence, prevalence and mortality of stroke show huge differences from one country to another. The incidence rates of stroke in the USA are the highest in the world, with 780,000 cases annually; 150,000 deaths occurred in 2004. Its prevalence was approximately 5.8 million, of which $87 \%$ was ischemic stroke [8]. The incidence of stroke is smaller in European populations than in the USA, with large geographical variations in 
incidence rates, which show a decreasing gradient from eastern to western European countries [9].

The strict classification of ischemic stroke into subtypes is crucial if we are to understand its etiology. It can be divided into three major subgroups depending on the pathogenic mechanism: thrombotic, embolic and hemodynamic stroke. This classification is based on results provided by imaging studies, and although there can be overlap between the groups, the classification is still relevant for prevention and management purposes.

The first major clinical classification was introduced in 1991 with the Oxford Community Stroke Project [10], which was followed by a more widely accepted one in 1993. This was developed for the Trial of Org10172 in Acute Ischemic Stroke (TOAST) [11] and was based on the most common pathophysiological mechanisms involved in the development of stroke (Table 1). The system comprises five subgroups: (1) the large-vessel atherosclerotic type, in which patients have cortical or cerebellar lesions and/or brainstem infarcts or subcortical hemispheric infarcts greater than $1.5 \mathrm{~cm}$ in diameter on magnetic resonance imaging (MRI), with or without cerebral cortical impairment or brainstem or cerebellar dysfunction; (2) the small-vessel occlusion type, which includes patients with one or more subcortical hemispheric or brainstem infarcts with a diameter less than $1.5 \mathrm{~cm}$ on MRI, with one of the features of the traditional clinical lacunar syndrome (a constellation of clinical symptoms (pure motor stroke, pure sensory stroke, sensorimotor stroke and ataxic hemiparesis), and signs at the time of maximum deficit following a single cerebrovascular event) and without cerebral cortical dysfunction; (3) the cardioembolic subtype, which comprises patients with arterial occlusions presumably resulting from an embolus arising in the heart; (4) stroke with other determined etiology, which includes patients with rare causes of stroke, such as hematological disorders, non-atherosclerotic vasculopathies and hypercoagulability (increase in coagulability); and (5) stroke with unidentified etiology, in which the cause of stroke cannot be determined [11].

Stroke is a multifactorial disease. Environmental factors can have a crucial role in the development of the disease. Several risk factors have been identified, which were categorized as potentially modifiable and nonmodifiable [12-14]. Age, gender and previous history of stroke are some of the non-modifiable risk factors, whereas hypertension, diabetes mellitus, obesity, elevated triglyceride and cholesterol levels, smoking, high alcohol consumption and presence of cardiovascular events are some modifiable risk factors.

Recently, the potential role for several naturally occurring genomic variants has come into the focus of epidemiological studies. Significant progress has already
Table 1. Classification of stroke subtypes from TOAST [12]

\begin{tabular}{ll}
\hline Subtype & Classification \\
\hline 1 & Large-artery atherosclerosis (embolus/thrombosis) \\
2 & Small-vessel occlusion (lacune) \\
3 & Cardioembolism (high-risk/medium-risk) \\
4 & Stroke of other determined etiology \\
5 & Stroke of undetermined etiology \\
& (a) Two or more causes identified \\
& (b) Negative evaluation \\
& (c) Incomplete evaluation
\end{tabular}

The classification of subtypes 1 to 4 includes possible or probable cases according to the results of ancillary studies as well as certain diagnoses.

been made in the identification of genetic variants for stroke and other cerebral and cardiovascular disorders [15-19], and research into these variants provides new insights into the pathogenesis of these conditions.

Rare forms of ischemic stroke appear as prime manifestations of multisystemic disorders, such as cerebral arteriopathy with subcortical infarcts and leukoencephalopathy (CADASIL), Fabry's disease, Marfan syndrome, and 'mitochondrial myopathy, encephalopathy, lactic acidosis and stroke-like episodes' (MELAS syndrome). These conditions show typically Mendelian or maternal inheritance and result from defects in single genes, such as $N O T C H 3, \alpha$-galactosidase (GLA), fibrillin-1 (FBN1) and mitochondrial tRNA-encoding genes, respectively [20-24]. Numerous studies have revealed single-gene disorders [25-32]; the discussion of these conditions is outside the scope of this article.

\section{Three periods in stroke susceptibility research Classic genetic risk factors for stroke}

The first studies into the genetic background of stroke involved the examination of single genetic variants that might be involved in pathogenic mechanisms of this condition. This period (approximately 1985 to 1995), which can be regarded as the first wave of stroke genetic research, was also the beginning of susceptibility allele research for numerous other multifactorial diseases, including ischemic heart disease, type 2 diabetes and metabolic syndrome. Several polymorphisms of genes influencing hemostasis and homocysteine metabolism and genes encoding enzymes involved in the reninangiotensin system and nitric oxide (NO) production were identified as risk factors for ischemic stroke (Tables 2 and 3 ).

Disturbances in the balance of hemostasis can lead to increased aggregation of blood platelets and thrombus formation, which may result from defects in genes encoding components of the coagulation cascade, such as factors II, V, XIII and fibrinogen, promoting the 
Table 2. Genes and their polymorphisms associated with ischemic stroke in GWASs

\begin{tabular}{|c|c|c|c|}
\hline System & Gene & Polymorphism & References \\
\hline \multirow[t]{3}{*}{ Hemostasis } & Factor II (prothrombin) (+176930) & c. $20210 G>A$ & {$[39,41-43]$} \\
\hline & Factor V (Leiden) (*612309) & p.Arg506Gln & {$[33-40]$} \\
\hline & Factor XIII (+134570) & p.Val34Leu & {$[39,44,45]$} \\
\hline \multirow[t]{2}{*}{ Renin-angiotensin system } & ACE $(+106180)$ & Insertion/deletion & {$[40,48-51]$} \\
\hline & $\operatorname{AT1R}(* 106165)$ & C. $1166 \mathrm{~A}>\mathrm{C}$ & {$[52-55]$} \\
\hline Nitric-oxide-synthase system & eNOS (+163729) & p.Glu298Asp & {$[56-58]$} \\
\hline Homocysteine metabolism & MTHFR $\left.{ }^{*} 607093\right)$ & C.677C $>$ T and C.1298A $>C$ & {$[43,59-61]$} \\
\hline Lipid metabolism & APOE $(+107741)$ & $\varepsilon 4, \varepsilon 3, \varepsilon 2$ & {$[40,46,62-66]$} \\
\hline
\end{tabular}

$A C E$, angiotensin converting enzyme; $A P O E$, apolipoprotein $\mathrm{E} ; A T 1 R$, angiotensin-receptor; eNOS, endothelial nitric oxide synthase; MTHFR,

5,10-methylenetetrahydrofolate reductase.

Table 3. Functional SNPs associated with ischemic stroke

\begin{tabular}{|c|c|c|c|}
\hline System & Gene & Polymorphism & References \\
\hline \multirow[t]{6}{*}{ Lipid metabolism } & APOA5 (*606368) & g. $-1131 \mathrm{~T}>\mathrm{C}, \mathrm{c} .1259 \mathrm{~T}>\mathrm{C}, \mathrm{c} .56 \mathrm{C}>\mathrm{G}, \mathrm{c} . \mathrm{IVS} 3+476 \mathrm{G}>\mathrm{A}$ & {$[82-88]$} \\
\hline & APOCIII (*107720) & g. $-2854 \mathrm{~T}>\mathrm{G}, \mathrm{g} .455 \mathrm{C}>\mathrm{T}, \mathrm{g} .-482 \mathrm{C}>\mathrm{T}, \mathrm{c} .3238 \mathrm{C}>\mathrm{G}$ & {$[73-76]$} \\
\hline & LPL ( $\left.{ }^{*} 609708\right)$ & p.Asn291Ser & {$[92-95]$} \\
\hline & GCKR $\left({ }^{*} 600842\right)$ & c. $1337 C>T$ & [104] \\
\hline & MLXIPL (*605678) & rs17145738, rs3812316 & [105] \\
\hline & GALNT (*602274) & rs4846914 & [104] \\
\hline Signal transduction & PDE4D (*600129) & Six SNPs, haplotypes & [96-100] \\
\hline Inflammation & ALOX5AP (*603700) & Seven SNPs, haplotypes & {$[97,100-103]$} \\
\hline
\end{tabular}

ALOX5AP, arachidonate 5-lipoxygenase-activating protein; APOA5, apolipoprotein A5; APOCIII, apolipoprotein CIII; LPL, lipoprotein lipase; PDE4D, phosphodiesterase $4 \mathrm{D}$.

development of several cardio- and cerebrovascular phenotypes. Activated factor $\mathrm{V}$ acts as a cofactor for the conversion of prothrombin to thrombin. Bertina and coworkers [33] first identified a c.1691G $>$ A transition (p.Arg506Gln) in the F5 gene in a family with thrombophilia in 1994. The c.1691G $>$ A alteration (called the Leiden variant) has been reported to be associated with resistance to degradation by activated protein C. Since then, numerous studies have examined this variant in several conditions that correlate with thromboembolism, but the results were inconsistent regarding the pathological role of this alteration [34-37]. According to the results of a large-scale epidemiological assessment, carriage of the 1691A allele was not associated with an increased risk of stroke [38]. However, a statistically significant association was found between the presence of the c.1691G>A transition and ischemic stroke in a meta-analysis [39]. We [40] found that the c.1691G>A alteration does not confer risk for stroke alone, but in combination with other unfavorable factors, such as hypertension or diabetes mellitus, it can increase the relative risk of ischemic stroke.

The most extensively studied alteration of the prothrombin (factor II) gene is c.20210G $>$ A, which was first described in 1996 [41]. This sequence variation is associated with elevated prothrombin levels. Several studies found a statistically significant association between ischemic stroke and this substitution [42,43]; the data of a meta-analysis also suggested that the c.20210G >A variant is a risk factor for ischemic stroke [39].

The p.Val34Leu substitution in factor XIII has also been suggested as a risk factor, but its role remains ambiguous according to the findings of association studies $[44,45]$. A meta-analysis by Casas and colleagues [39] suggested that the p.Val34Leu variant does not confer an increased risk for development of stroke.

The c.455G>A alteration of the fibrinogen-encoding gene has been found to occur more frequently in homozygous form in patients with large-vessel stroke [46]. Carrying the rare allele causes elevated fibrinogen levels, which confers susceptibility to ischemic stroke by prothrombotic mechanisms. A similar relationship was found for other variants of the fibrinogen gene, but only in female patients [47].

The renin-angiotensin system regulates blood pressure and water balance. Renin, the key protease of the cascade, is secreted from the kidneys and cleaves angiotensinogen to form angiotensin I. This intermediate form is then 
converted to angiotensin II by angiotensin converting enzyme (ACE). The ACE gene, located on chromosome 17 , is one of the most intensively studied candidate genes associated with ischemic stroke. Cambien and colleagues [48] first described the insertion/deletion (indel) polymorphism of the gene in myocardial infarction. Six years later, a meta-analysis reported a significant positive association between the deletion polymorphism of the $A C E$ gene and ischemic stroke [49]. The results of a large, prospective study indicate that the $A C E$ indel polymorphism is not associated with subsequent risk of stroke [50]. In a Hungarian population we have found the ACE $\mathrm{D} / \mathrm{D}$ variants (homozygous carriers of the deletion) to be associated with risk for development of stroke [40,51]. Subsequent studies have mostly investigated variants of the gene encoding angiotensin II receptor type I (AT1R c. $1166 \mathrm{~A}>C$ ). AT1R has multiple effects, both cardiac and systemic, mediating vasoconstriction, cellular hypertrophy and catecholamine release. In a Caucasian population a weak association was found between carrying the AT1R $1166 \mathrm{C}$ allelic variant and stroke [52,53]. According to our results [54], the $1166 \mathrm{C}$ allelic variant is associated with susceptibility to the disease among hypertensive smokers. We found co-occurrence of $A C E$ indel and $A T 1 R$ c. $1166 \mathrm{~A}>\mathrm{C}$ variants to confer risk for small-vessel occlusion type stroke in a Hungarian population [55]. Several studies have investigated $A C E$ indel polymorphisms in association with numerous conditions, and they are believed to contribute to the development of atherosclerotic mechanisms, but their role remains controversial.

The NO synthase system is an important regulator of the integrity and growth of the vascular endothelium and is responsible for the maintenance of normal endothelial function. The endothelial nitric oxide synthase (eNOS) enzyme converts L-arginine to Lcitrulline, generating $\mathrm{NO}$ in the arteries, and has a role in vasodilation. Under pathological conditions, cells produce superoxide instead of NO, which can initiate the atherosclerotic process. In 1996, Wang and colleagues [56] first identified a functional variant (eNOS4a/b) of the $e N O S$ gene in association with coronary artery disease. Since then, several reports have studied variants in $e N O S$ in relation to ischemic stroke. Howard and colleagues [57] found that a promoter region polymorphism $(-786 \mathrm{~T}>\mathrm{C})$ of $e N O S$ is associated with ischemic stroke susceptibility in young black women. Another single-nucleotide polymorphism (SNP) in this gene (c.894G>T) has been shown not to be a susceptibility factor for ischemic stroke; however, co-occurrence with other SNPs, such as ACE D/D or the $\mathrm{c} .677 \mathrm{C}>\mathrm{T}$ in the 5,10 -methylenetetrahydrofolate reductase (MTHFR) gene, could increase stroke risk [58].
Hyperhomocysteinemia caused by pathological homocysteine metabolism has been associated with increased risk for several cardio- and cerebrovascular events. Elevated homocysteine levels can result from reduction or complete absence of MTHFR enzyme activity, which catalyzes the methylation of homocysteine. Variants in the MTHFR gene (c.677C $>\mathrm{T}$ or c.1298A $>$ C) can lead to deficiencies in enzyme activity. The c. $677 \mathrm{C}>\mathrm{T}$ alteration was found to be an important risk factor for cerebral events. Examination of these polymorphisms revealed no association between carriage of the $677 \mathrm{~T}$ or $1298 \mathrm{C}$ alleles and development of stroke $[43,59]$. However, we [60] reported that co-occurrence of these two alleles confers susceptibility to ischemic stroke, in both heterozygous and homozygous carriers. A casecontrol study [61] demonstrated that the 677T allelic variant is more prevalent in ischemic stroke patients in co-occurrence with the $A T 1 R$ c. $1166 \mathrm{~A}>\mathrm{C}$ variant, and together they confer increased risk for stroke.

Apolipoprotein E, the main apoprotein in the lipoprotein-transporting chylomicron particles, serves as a ligand for cellular receptors on liver and peripheral cells and interacts with proteoglycans on the endothelium to guide lipoproteins to lipases. The APOE gene, located on chromosome 19 , is polymorphic, with three co-dominant alleles, $\varepsilon 2, \varepsilon 3$ and $\varepsilon 4$, defining six genotypes [62]. Carriers of the $\varepsilon 2$ alleles have lower total and low-density lipoprotein (LDL)-cholesterol levels and elevated triglyceride levels. Carriers of the $\varepsilon 4$ allele have higher levels of both total and LDL-cholesterol than $\varepsilon 3 / \varepsilon 3$ homozygotes [63]. Multiple studies have shown that $A P O E$ is an important predicting factor for the development of ischemic stroke [46,64-66]. We [40] observed that the $A P O E \& 4$ allele alone represents a minor genetic risk factor for ischemic stroke. However, the co-occurrence of the $A P O E \& 4$ allele and traditional risk factors, such as hypertension, diabetes mellitus, smoking and alcohol consumption, results in a considerably elevated risk for ischemic stroke.

\section{Further search for functional SNPs in stroke}

In the second period of stroke research (approximately 1995 to 2007), the identification of functional variants as possible susceptibility genes increased rapidly. Increased concentrations of plasma lipids, triglyceride and cholesterol levels were found to be independent risk factors for cardio- and cerebrovascular disorders [67-69]. Plasma triglyceride levels are determined by numerous genes and their interactions with the environment. The search for genetic variations affecting plasma triglyceride concentrations is still ongoing; several loci identified so far include the apolipoprotein genes APOAI, APOCIII, $A P O A I V$, and $A P O A 5$ and the lipoprotein lipase $(L P L)$ gene $[66,70]$. 
Apolipoproteins are lipid binding proteins involved in the plasma transport of lipids. They can activate or inhibit enzymes involved in lipoprotein metabolism or serve as signals for receptors in the liver or other cells. Genetic variations influencing their protein structure or synthesis may affect lipid metabolism, resulting in progression to cardio- and cerebrovascular disorders. The currently known apolipoproteins are APOAI, APOAII, APOAIV, APOA5, APOB48, APOB100, APOCI-APOCIII and APOE. The APOAI, APOCIII and $A P O A I V$ genes on chromosome 11 are so far the most intensively studied genes [71]. APOCIII encodes a protein of 79 amino acids that is synthesized in the liver and the intestines and is an essential constituent of circulating particles, such as very low density lipoprotein (VLDL) and chylomicrons [72]. Several polymorphisms of APOCIII have been associated with hypertriglyceridemia [73]. Carriers of the $\mathrm{G}$ allele of the c.3238C $>\mathrm{G}$ polymorphism in the APOCIII 3' untranslated region (UTR) were reported to have higher plasma triglyceride concentrations, as were individuals with two minor alleles $(-482 \mathrm{C}>\mathrm{T}$ and $-455 \mathrm{~T}>\mathrm{C})$ of the APOCIII promoter [74,75]. Because APOCIII inhibits the hydrolysis of triglyceride-rich particles by lipoprotein lipase, its overexpression leads to hypertriglyceridemia [72]. Only a few studies have explored the role of the APOCIII gene g.8017G >C (rs5128) polymorphism in the development of ischemic stroke. Aalto-Setälä and colleagues [76] found a negative association between this APOCIII polymorphism and ischemic stroke.

The APOA5 gene is located near the APOAI-APOCIII$A P O A I V$ cluster and encodes a 366 amino acid protein [77]. The mature APOA5 protein is synthesized in the liver and secreted into the plasma [78]. Evidence supports a central regulatory role for APOA5 in triglyceride metabolism through the inhibition of hepatic VLDL production or by guiding VLDL and chylomicrons to proteoglycan-bound lipoprotein lipase $[79,80]$. Furthermore, APOA5 has been described to independently influence plasma triglyceride levels in an opposing manner to APOCIII [81]. Around 40 polymorphisms of the APOA5 gene have been identified since the discovery of the gene [82-84]. These natural variants may alter the function of the protein. The most common variants, $-1131 \mathrm{~T}>\mathrm{C}$ (rs662799) in the promoter region, g.1259T >C (rs2266788) in the 3' UTR region, c.56C>G (rs3135506, resulting in a serine-to-tryptophan amino acid change in the signal peptide), and intronic g.IVS3+476G $>$ A (rs2072560;) have been repeatedly linked with elevated triglyceride levels $[77,84,85]$. Some of them have also been found to be independent risk factors for several conditions of triglyceride metabolism. The carriage of $-1131 \mathrm{C}$ and g.IVS3+476A mutant alleles have been established to confer increased risk for all subtypes of ischemic stroke [86,87]. In Hungarian individuals, we found the $56 \mathrm{G}$ allele to be associated only with largevessel stroke [88], but found the $1259 \mathrm{C}$ variant not to be associated with an increased risk for the disease [87]. The most common SNPs of APOA5 are in strong linkage disequilibrium and constitute haplotype variants designated by asterisks (APOA5*2, $3, * 4$ and $* 5)$. Among these, $A P O A 5^{*} 2$ was ascertained to be a risk factor for ischemic stroke. In any case, $A P O A 5$ is an example of shared susceptibility: we have found this naturally occurring variant and haplotypes to also confer susceptibility to other diseases, such as metabolic syndrome [89-91].

LPL is another important enzyme for triglyceride metabolism; it catalyzes the hydrolysis of chylomicron- and VLDL-associated triglycerides with the cofactor APOCII [92]. Approximately 100 polymorphisms have been described in the $L P L$ gene. Most of these variants can lead to decreased LPL activity, which increases plasma triglyceride levels and the risk of atherosclerosis [93]. Huang et al. [94] found that the p.Asn291Ser alteration has a significant influence on serum levels of triglycerides, but this polymorphism does not contribute greatly to the overall risk of ischemic stroke. The results of a subsequent study [95] suggest that the p.Asn291Ser substitution is not associated with ischemic stroke in men but it possibly confers a twofold risk in women.

cAMP-specific 3,'5'-cyclic phosphodiesterase 4D (PDE4D) is an important regulator of proliferation of smooth muscle cells and macrophages, acting by degrading a key signaling molecule, cAMP. Defects in the protein result in the accumulation of cAMP in various cell types, such as monocytes and $\mathrm{T}$ lymphocytes. It can inhibit immune functions, such as proliferation and cytokine secretion, which can lead to atherosclerosis and plaque instability. The gene located on chromosome 5 encoding PDE4D was identified by Gretarsdottir et al. in 2003 [96]. Among the 260 SNPs examined by the authors [96], six have been found to be associated with stroke. Haplotype analyses have also shown significant correlation between certain haplotypes and ischemic stroke. Sixteen replication studies have since been published on the association between SNPs in PDE4D and ischemic stroke in different populations, with divergent results. Some of them confirmed the previously described positive association $[97,98]$, whereas others dispute an association $[99,100]$. The inconsistent results may originate from differences between the population samples analyzed.

The gene encoding arachidonate 5-lipoxygenaseactivating protein $(A L O X 5 A P)$ has also been the focus of association studies. ALOX5AP is a proinflammatory mediator that is implicated in the pathogenesis and progression of atherosclerosis. Several polymorphisms and haplotypes were identified in $A L O X 5 A P$ that have 
been shown to confer increased risk for stroke in an Icelandic population [101]. This result was confirmed in German and Scottish populations [102,103]. However, some studies [97] found no association between the presence of polymorphisms in ALOX5AP and clinical phenotypes. Further investigation into the functional consequences of these variants is under way.

Before genome-wide association studies (GWASs) were used to study stroke, they were applied to other common diseases, such as Parkinson's disease, myocardial infarction, inflammatory bowel disease, and even relatively rare conditions, such as macular degeneration. However, variants discovered in GWASs focusing on alleles involved in triglyceride metabolism, such as a variant (rs780094) of the glucokinase regulatory protein (GCKR), which is associated with increased triglyceride levels, were also investigated in relation to stroke [66,70]. The GCKR gene, located on chromosome 2, encodes a protein of 625 amino acids that inhibits glucokinase in liver and pancreatic cells by binding the enzyme non-covalently to form an inactive complex. Járomi et al. [104] investigated the GCKR c.1337C>T (rs1260326) variant in a casecontrol study on a stratified stroke population; no association could be detected of GCKR alleles with triglyceride levels or with the susceptibility to stroke.

GWAS analysis has also identified SNPs localized at the GALNT2 and MLXIPL-TBL2 loci as being associated with increased triglyceride levels [66,70]. The rs4846914 variant is an intronic variant of the UDP- $N$-acetyl- $\alpha$-Dgalactosamine:polypeptide $N$-acetylgalactosaminyltransferase 2 (GALNT2) gene, and its minor $\mathrm{G}$ allele was reported to associate with higher triglyceride concentrations. The GALNT2 gene is responsible for the transfer of an $\mathrm{N}$-acetyl galactosamine to the hydroxyl group of a serine or threonine residue in the first step of $O$-linked oligosaccharide biosynthesis. Our Hungarian casecontrol study [104] evaluated the association of the GALNT2 rs4846914 variant with triglyceride levels and explored their possible contribution to the development of ischemic stroke. No positive association was detected either with triglyceride levels or with susceptibility to the disease [104].

The major alleles of the rs17145738 and rs3812316 variants within the MLXIPL-TBL2 region have been found to be associated with increased triglyceride levels [66,70]. MLXIPL encodes a transcription factor, MXL interacting protein-like, which has a role in the activation of carbohydrate response element motifs in the promoter region of genes involved in lipogenesis and triglyceride synthesis and regulates lipogenesis and glucose utilization in the liver. TBL2 encodes transducin $\beta$-like 2 protein, which is thought to be involved in intracellular signaling. We [105] examined the effect of rs17145738 and rs3812316 variants on triglyceride levels and on stroke susceptibility. The results showed that the presence of these variants did not result in elevated triglyceride levels and did not confer risk for ischemic stroke.

\section{Genome-wide association studies in ischemic stroke}

The first GWAS directly focused on ischemic stroke patients was published in 2007 [106] (see Table 4 for a summary of GWASs reported so far in association with ischemic stroke). Matarín and colleagues [106] analyzed 278 ischemic stroke patients and 275 controls for more than 408,000 unique SNPs using Illumina Infinium Human-1 and HumanHap300 assays. The ischemic stroke subtypes were allocated according to the specified TOAST classification. The results showed hundreds of nominally statistically significant associated markers, among them the most notable candidate loci are inositol(myo)-1(or 4)-monophosphatase 2 (IMPA2) on chromosome 18, which is involved in the phosphatidylinositol signaling pathway, and $\mathrm{Kv}$ channel interacting protein 4 (KCNIP4) on chromosome 4 and potassium channel K17 (KCNK17) on chromosome 6, which are involved in potassium transport [106].

In 2008, Gretarsdottir and colleagues [107] described the results of a well powered GWAS with 1,661 ischemic stroke patients from the Icelandic population, classified according to TOAST, and 10,815 controls. The authors used Illumina Infinium Human-1 and HumanHap300 chips for genome-wide genotyping of more than 310,000 SNPs, from which 120 were selected for replication. Among those, rs2200733 and rs10033464 in the gene encoding the transcriptional activator PITX on chromosome 4q25 were found to be significantly associated with the development of ischemic stroke, especially for stroke due to cardioembolism (cardiogenic stroke) [107]. Some variants identified in the gene have previously been associated with Axenfeld-Rieger syndrome, which is a rare autosomal dominant, genetically heterogeneous disorder characterized by abnormal development of the anterior segment of the eye resulting in ocular changes and accompanied by systemic features, such as craniofacial dysmorphism, dental anomalies and cardiac malformations [108,109].

A Japanese GWAS [110], which included 6,341 participants (992 ischemic stroke patients and 5,349 controls), analyzed more than 520,000 SNPs using the GeneChip Human Mapping 500K Array from Affymetrix and selected 100 SNPs for replication. This study [110] reported polymorphisms in the cadherin EGF LAG sevenpass G-type receptor 1 (CELSR1) gene on chromosome 22 as susceptibility factors for ischemic stroke. CELSR 1 encodes a transmembrane G-protein-coupled receptor.

Ikram et al. [111] carried out a combined analysis of GWAS data generated from four large cohorts 
Table 4. Genome-wide association studies on stroke

\begin{tabular}{|c|c|c|c|c|c|c|c|c|}
\hline \multirow[b]{2}{*}{ Population } & \multirow[b]{2}{*}{ Sample size } & \multirow{2}{*}{$\begin{array}{l}\text { Sample size } \\
\text { in replication }\end{array}$} & \multirow{2}{*}{$\begin{array}{l}\text { Number } \\
\text { of SNPs } \\
\text { examined }\end{array}$} & \multirow{2}{*}{$\begin{array}{l}\text { Number } \\
\text { of SNPs } \\
\text { examined in } \\
\text { replication }\end{array}$} & \multicolumn{2}{|c|}{ Positive association } & \multirow[b]{2}{*}{ Platform } & \multirow[b]{2}{*}{ References } \\
\hline & & & & & Gene & Variant & & \\
\hline Caucasian & $\begin{array}{c}1164 \text { cases, } \\
18438 \text { controls }\end{array}$ & $\begin{array}{c}3656 \text { cases, } \\
3,613 \text { controls }\end{array}$ & $2,194,468$ & 2 & $\begin{array}{l}\text { Near NINJ2 } \\
\text { and WNK1 }\end{array}$ & $\begin{array}{l}\text { rs11833579, } \\
\text { rs12425791 }\end{array}$ & $\begin{array}{l}\text { Affymetrix, } \\
\text { Illumina }\end{array}$ & [111] \\
\hline Japanese & $\begin{array}{c}992 \text { cases, } \\
5349 \text { controls }\end{array}$ & $\begin{array}{c}705 \text { cases, } \\
3,426 \text { controls }\end{array}$ & 520,000 & 100 & $\begin{array}{c}\text { CELSR1 } \\
\left({ }^{*} 604523\right)\end{array}$ & $\begin{array}{l}\text { rs6007897, } \\
\text { rs } 4044210\end{array}$ & Affymetrix & [110] \\
\hline Caucasian & $\begin{array}{c}\text { 1,661 cases, } \\
10,815 \text { controls }\end{array}$ & $\begin{array}{c}\text { 2,224 cases, } \\
2,583 \text { controls } \\
\text { or 2,327 cases, } \\
16,760 \text { controls }\end{array}$ & 310,881 & 120 & $\begin{array}{l}\text { Near PITX2 } \\
\left({ }^{*} 601542\right)\end{array}$ & $\begin{array}{l}\text { rs22200733, } \\
\text { rs10033464 }\end{array}$ & Illumina & [107] \\
\hline US & $\begin{array}{c}249 \text { cases, } \\
268 \text { controls }\end{array}$ & - & 408,000 & - & $\begin{array}{l}\text { IMPA2 }\left({ }^{*} 605922\right), \\
\text { KCNIP4 }\left({ }^{*} 608182\right), \\
\text { KCNK17 }\left({ }^{*} 607370\right.\end{array}$ & rs7506045 & Illumina & {$[106]$} \\
\hline
\end{tabular}

CELSR1, cadherin EGF LAG seven-pass G-type receptor 1; IMPA2, inositol(myo)-1(or 4)-monophosphatase 2; KCNIP4, Kv channel interacting protein 4; KCNK17, potassium channel, subfamily K, member 17; NINJ2, Nerve injury-induced protein 2; PITX2, paired-like homeodomain 2.

(Framingham Heart Study, Rotterdam Study, ARIC and Cardiovascular Health Study). The cohorts include 19,602 participants, of whom 1,164 were patients having suffered ischemic stroke. The genotyping was performed with different platforms (Affymetrix GeneChip SNP Array 6.0, GeneChip Human Mapping 500K Array and 50K Human Gene Focused Panel; Illumina HumanCNV370-Duo and Infinium HumanHap550 3.0). Two of the analyzed SNPs, rs11833579 and rs12415791 on chromosome 12 near the nerve injury-induced protein 2 (NINJ2) and WNK lysine deficient protein kinase 1 (WNK1) genes, were confirmed in the replication study, which revealed a positive association between carrying minor alleles and ischemic stroke, in particular the atherothrombotic stroke subtype [111].

Despite their huge power and impact, GWASs also have limitations. In a few cases [110], the studies involved a single population. Validation of the findings in different ethnic groups will be required. In certain replication studies [106], the number of participants was too small and the functional relevance of the identified polymorphisms remains unclear. Further genotyping as well as detailed functional and epidemiological studies in larger populations are therefore required to identify the exact role and associations of these genes and gene variants in the development of ischemic stroke.

\section{Concluding remarks}

Significant progress has been seen in the field of stroke susceptibility genetics over the past one and a half decades; however, research intensity has been moderate in comparison with other multifactorial diseases, such as diabetes, metabolic syndrome or ischemic heart diseases. It has become clear that stroke shows a complex phenotype and, as a result, a careful stratification of the patients is essential, as the genetic etiology can differ strongly between the subtypes. An imbalance in research intensity can also be observed for the different stroke groups: causative genes are still to be discovered for some Mendelian forms, whereas in the polygenic groups the majority of efforts are mainly restricted to the small- and large-vessel associated stroke variants, with less frequent rare variants receiving little attention. Thus, although the available biobanks have been valuable for moving smalland large-vessel associated stroke pathology research forwards, they should be strengthened with additional samples from the less frequent stroke types. This may not be a simple task, given the small incidence rates of these rare variants.

As has occurred for other diseases, the recent GWAS area has opened new perspectives for susceptibility gene research in relation to stroke. It is now clear that some susceptibility alleles can be shared: the same allele can confer susceptibility to stroke, ischemic heart diseases or even metabolic syndrome. Some susceptibility factors that are associated with clinical traits can themselves also be risk factors for stroke: thus, alleles associated with increased triglyceride levels can also be susceptibility factors for stroke. The possible association between triglyceride levels and stroke is an old question; future association studies will help us understand which naturally occurring genetic variants associate with increased triglycerides alone without stroke and which variants also associate with cerebral pathology. In a broader context, better knowledge about different metabolic and biochemical parameters in the healthy population will also help us to understand their potential role in the development of stroke [112].

Although susceptibility allele tests are offered on the palette of some direct-to-consumer companies, we have to keep in mind that current evidence does not yet support their use in clinical practice [113-118] given that 
the predictive value of these test results is still limited. The rapid spread of exome sequencing and wholegenome sequencing techniques will probably help us to identify novel genes in stroke types that have a Mendelian monogenic origin, even for rare stroke types, rather than helping to understand the complex pathology associated with polygenic types of stroke.

\section{Abbreviations}

ACE, angiotensin converting enzyme; ALOX5AP, arachidonate 5-lipoxygenaseactivating protein; APO, apolipoprotein; AT1R, angiotensin receptor; CELSR1, cadherin EGF LAG seven-pass G-type receptor 1; eNOS, endothelial nitric oxide synthase; GCKR, glucokinase regulatory protein; GALNT2, UDP-N-acetylalpha-D-galactosamine:polypeptide, $\mathrm{N}$-acetylgalactosaminyltransferase 2 ; GWAS, genome-wide association study; IMPA2, inositol(myo)-1(or 4)-monophosphatase 2; KCNIP4, Kv channel interacting protein 4; KCNK17, potassium channel K17; LPL, lipoprotein lipase; MLXIPL, MLX interacting protein-like; MRI, magnetic resonance imaging; MTHFR, 5,10-methylenetetrahydrofolate reductase; NINJ2, nerve injury-induced protein 2; PDE4D, phosphodiesterase 4D; PITX, paired-like homeodomain 2 SNP, single-nucleotide polymorphism; TBL2, transducin (beta)-like 2; TOAST, Trial of Org10172 in Acute Ischemic Stroke; VLDL, very low density lipoprotein; WNK1, WNK lysine deficient protein kinase 1.

\section{Competing interests}

The authors declare that they have no competing interests.

\section{Authors' contributions}

Both authors contributed equally in the preparation of the review.

\section{Acknowledgements}

Original research papers related to this work were supported by the grant of Hungarian Scientific Research Foundation OTKA T 73430 and from the grant of the Hungarian Ministry of Health: ETT 243/2009.

\section{Published: 13 September 2010}

\section{References}

1. Truscott BL: WHO on stroke. Ann Intern Med 1972, 76:139-140.

2. Walt G: WHO's World Health Report 2003. BMJ 2004, 328:6.

3. Feigin VL, Lawes CM, Bennett DA, Anderson CS: Stroke epidemiology: a review of population-based studies of incidence, prevalence, and case-fatality in the late 20th century. Lancet Neurol 2003, 2:43-53.

4. Murray CJ, Lopez AD: Global mortality, disability, and the contribution of risk factors: Global Burden of Disease Study. Lancet 1997, 349:1436-1442.

5. Poungvarin N: Stroke in the developing world. Lancet 1998, 352 Suppl 3:SIII19-SIII22.

6. Bonita R, Mendis S, Truelsen T, Bogousslavsky J, Toole J, Yatsu F: The global stroke initiative. Lancet Neurol 2004, 3:391-393.

7. Donnan GA, Fisher M, Macleod M, Davis SM: Stroke. Lancet 2008, 371:1612-1623.

8. Rosamond W, Flegal K, Furie K, Go A, Greenlund K, Haase N, Hailpern SM, Ho M, Howard V, Kissela B, Kittner S, Lloyd-Jones D, McDermott M, Meigs J, Moy C, Nichol G, O'Donnell C, Roger V, Sorlie P, Steinberger J, Thom T, Wilson M, Hong Y: Heart disease and stroke statistics - 2008 update: a report from the American Heart Association Statistics Committee and Stroke Statistics Subcommittee. Circulation 2008, 117:e25-e146.

9. Strong K, Mathers C, Bonita R: Preventing stroke: saving lives around the world. Lancet Neurol 2007, 6:182-187.

10. Bamford J, Sandercock P, Dennis M, Burn J, Warlow C: Classification and natural history of clinically identifiable subtypes of cerebral infarction. Lancet 1991, 337:1521-1526.

11. Adams HP Jr, Bendixen BH, Kappelle LJ, Biller J, Love BB, Gordon DL, Marsh EE III: Classification of subtype of acute ischemic stroke. Definitions for use in a multicenter clinical trial. TOAST. Trial of Org 10172 in Acute Stroke Treatment. Stroke 1993, 24:35-41.

12. Sacco RL, Benjamin EJ, Broderick JP, Dyken M, Easton JD, Feinberg WM, Goldstein LB, Gorelick PB, Howard G, Kittner SJ, Manolio TA, Whisnant JP, Wolf PA: American Heart Association Prevention Conference. IV. Prevention and rehabilitation of stroke. Risk factors. Stroke 1997, 28:1507-1517.
13. Cubrilo-Turek M: Stroke risk factors: recent evidence and new aspects. Int Congr Ser 2004, 1262:466-469.

14. Lipska K, Sylaja PN, Sarma PS, Thankappan KR, Kutty VR, Vasan RS, Radhakrishnan K: Risk factors for acute ischaemic stroke in young adults in South India. J Neurol Neurosurg Psychiatry 2007, 78:959-963.

15. Allen JK: Genetics and cardiovascular disease. Nurs Clin North Am 2000, 35:653-662.

16. Hassan A, Markus HS: Genetics and ischaemic stroke. Brain 2000, 123:1784-1812.

17. Flossmann E: Genetics of ischaemic stroke; single gene disorders. Int J Stroke 2006, 1:131-139.

18. Morgan L, Humphries SE: The genetics of stroke. Curr Opin Lipidol 2005, 16:193-199.

19. Dichgans M: Genetics of ischaemic stroke. Lancet Neurol 2007, 6:149-161.

20. Joutel A, Corpechot C, Ducros A, Vahedi K, Chabriat H, Mouton P, Alamowitch S, Domenga V, Cécillion M, Marechal E, Maciazek J, Vayssiere C, Cruaud C, Cabanis EA, Ruchoux MM, Weissenbach J, Bach JF, Bousser MG, TournierLasserve E: Notch3 mutations in CADASIL, a hereditary adult-onset condition causing stroke and dementia. Nature 1996, 383:707-710.

21. Joutel A, Vahedi K, Corpechot C, Troesch A, Chabriat H, Vayssière C, Cruaud C, Maciazek J, Weissenbach J, Bousser MG, Bach JF, Tournier-Lasserve E: Strong clustering and stereotyped nature of Notch3 mutations in CADASIL patients. Lancet 1997, 350:1511-1515.

22. Rolfs A, Böttcher T, Zschiesche M, Morris P, Winchester B, Bauer P, Walter U, Mix E, Löhr M, Harzer K, Strauss U, Pahnke J, Grossmann A, Benecke R: Prevalence of Fabry disease in patients with cryptogenic stroke: a prospective study. Lancet 2005, 366:1794-1796.

23. Hayward C, Keston M, Brock DJ, Dietz HC: Fibrillin (FBN1) mutations in Marfan syndrome. Hum Mutat 1992, 1:79.

24. Goto Y, Nonaka I, Horai S: A mutation in the tRNA(Leu)(UUR) gene associated with the MELAS subgroup of mitochondrial encephalomyopathies. Nature 1990, 348:651-653.

25. Chabriat H, Joutel A, Dichgans M, Tournier-Lasserve E, Bousser MG: Cadasil. Lancet Neurol 2009, 8:643-653

26. Ross OA, Meschia JF: Genetics of ischemic stroke: inheritance of a sporadic disorder. Curr Neurol Neurosci Rep 2009, 9:19-27.

27. Karetova D, Bultas J, Dostalova G, Palecek T, Kovarnik T, Golan L, Linhart A: Fabry disease - vascular manifestations. Vasa 2010, 39:123-131.

28. Schiffmann R: Fabry disease. Pharmacol Ther 2009, 122:65-77.

29. Gonzales EA: Marfan syndrome. J Am Acad Nurse Pract 2009, 21:663-670

30. Ho NC, Tran JR, Bektas A: Marfan's syndrome. Lancet 2005, 366:1978-1981.

31. Matsumoto J, Saver JL, Brennan KC, Ringman JM: Mitochondrial encephalomyopathy with lactic acidosis and stroke (MELAS). Rev Neurol Dis 2005, 2:30-34.

32. Edmond JC: Mitochondrial disorders. Int Ophthalmo/ Clin 2009, 49:27-33.

33. Bertina RM, Koeleman BP, Koster T, Rosendaal FR, Dirven RJ, de RH, van der Velden PA, Reitsma PH: Mutation in blood coagulation factor $\mathrm{V}$ associated with resistance to activated protein C. Nature 1994, 369:64-67.

34. Catto A, Carter A, Ireland H, Bayston TA, Philippou H, Barrett J, Lane DA, Grant $\mathrm{PJ}$ : Factor $\mathrm{V}$ Leiden gene mutation and thrombin generation in relation to the development of acute stroke. Arterioscler Thromb Vasc Biol 1995, 15:783-785.

35. Albucher JF, Guiraud-Chaumeil B, Chollet F, Cadroy Y, Sie P: Frequency of resistance to activated protein $\mathrm{C}$ due to factor $\mathrm{V}$ mutation in young patients with ischemic stroke. Stroke 1996, 27:766-767.

36. Press RD, Liu XY, Beamer N, Coull BM: Ischemic stroke in the elderly. Role of the common factor $\mathrm{V}$ mutation causing resistance to activated protein $\mathrm{C}$. Stroke 1996, 27:44-48.

37. De LD, Nina P, Papa ML, Belli A, Conte M, Renis V, Di MC, Masi S, Franco A Schisano G: Activated protein C resistance due to a factor $V$ mutation associated with familial ischemic stroke. J Neurosurg Sci 1997, 41:373-378

38. Ridker PM, Hennekens CH, Lindpaintner K, Stampfer MJ, Eisenberg PR, Miletich JP: Mutation in the gene coding for coagulation factor $\mathrm{V}$ and the risk of myocardial infarction, stroke, and venous thrombosis in apparently healthy men. N Engl J Med 1995, 332:912-917.

39. Casas JP, Hingorani AD, Bautista LE, Sharma P: Meta-analysis of genetic studies in ischemic stroke: thirty-two genes involving approximately 18,000 cases and 58,000 controls. Arch Neurol 2004, 61:1652-1661.

40. Szolnoki Z, Somogyvari F, Kondacs A, Szabo M, Fodor L, Bene J, Melegh B: Evaluation of the modifying effects of unfavourable genotypes on classical clinical risk factors for ischaemic stroke. J Neurol Neurosurg Psychiatry 2003, 74:1615-1620 
41. Poort SR, Rosendaal FR, Reitsma PH, Bertina RM: A common genetic variation in the $3^{\prime}$-untranslated region of the prothrombin gene is associated with elevated plasma prothrombin levels and an increase in venous thrombosis. Blood 1996, 88:3698-3703.

42. Martinelli I, Franchi F, Akwan S, Bettini P, Merati G, Mannucci PM: The transition $\mathrm{G}$ to $A$ at position 20210 in the $3^{\prime}$-untranslated region of the prothrombin gene is not associated with cerebral ischemia. Blood 1997, 90:3806.

43. De S, V, Chiusolo P, Paciaroni K, Casorelli I, Rossi E, Molinari M, Servidei S, Tonali PA, Leone G: Prothrombin G20210A mutant genotype is a risk factor for cerebrovascular ischemic disease in young patients. Blood 1998, 91:3562-3565.

44. Gemmati D, Serino ML, Ongaro A, Tognazzo S, Moratelli S, Resca R, Moretti M, Scapoli GL: A common mutation in the gene for coagulation factor XIII-A (VAL34Leu): a risk factor for primary intracerebral hemorrhage is protective against atherothrombotic diseases. Am J Hematol 2001, 67:183-188

45. Catto AJ, Kohler HP, Bannan S, Stickland M, Carter A, Grant PJ: Factor XIII Val 34 Leu: a novel association with primary intracerebral hemorrhage. Stroke 1998, 29:813-816.

46. Kessler C, Spitzer C, Stauske D, Mende S, Stadlmuller J, Walther R, Rettig R: The apolipoprotein $\mathrm{E}$ and beta-fibrinogen $\mathrm{G} / \mathrm{A}-455$ gene polymorphisms are associated with ischemic stroke involving large-vessel disease. Arterioscler Thromb Vasc Biol 1997, 17:2880-2884.

47. Carter AM, Catto AJ, Bamford JM, Grant PJ: Gender-specific associations of the fibrinogen B beta 448 polymorphism, fibrinogen levels, and acute cerebrovascular disease. Arterioscler Thromb Vasc Biol 1997, 17:589-594.

48. Cambien F, Poirier O, Lecerf L, Evans A, Cambou JP, Arveiler D, Luc G, Bard JM, Bara L, Ricard S, Tiret L, Amouyel P, Alhenc-Gelas F, Soubrier F: Deletion polymorphism in the gene for angiotensin-converting enzyme is a potent risk factor for myocardial infarction. Nature 1992, 359:641-644.

49. Sharma P: Meta-analysis of the ACE gene in ischaemic stroke. J Neurol Neurosurg Psychiatry 1998, 64:227-230.

50. Zee RY, Ridker PM, Stampfer MJ, Hennekens CH, Lindpaintner K: Prospective evaluation of the angiotensin-converting enzyme insertion/deletion polymorphism and the risk of stroke. Circulation 1999, 99:340-343.

51. Szolnoki Z, Melegh B: Gene-gene and gene-environment interplay represent specific susceptibility for different types of ischaemic stroke and leukoaraiosis. Curr Med Chem 2006, 13:1627-1634.

52. Rubattu S, Di AE, Stanzione R, Zanda B, Evangelista A, Pirisi A, De PP, Cota L, Brunetti $E$, Volpe M: Gene polymorphisms of the renin-angiotensinaldosterone system and the risk of ischemic stroke: a role of the $\mathrm{A} 1166 \mathrm{C} /$ AT1 gene variant. J Hypertens 2004, 22:2129-2134.

53. Brenner D, Labreuche J, Poirier O, Cambien F, Amarenco P: Reninangiotensin-aldosterone system in brain infarction and vascular death Ann Neurol 2005, 58:131-138

54. Szolnoki Z, Havasi V, Talián G, Bene J, Komlósi K, Somogyvári F, Kondacs A, Szabó M, Fodor L, Bodor A, Melegh B: Angiotensin II type-1 receptor A1166C polymorphism is associated with increased risk of ischemic stroke in hypertensive smokers. J Mol Neurosci 2006, 28:285-290

55. Szolnoki Z, Maasz A, Magyari L, Horvatovich K, Farago B, Somogyvari F, Kondacs A, Szabo M, Fodor L, Bodor A, Hadarits F, Melegh B: Coexistence of angiotensin II Type-1 receptor $A 1166 C$ and angiotensin-converting enzyme D/D polymorphism suggests susceptibility for small-vesselassociated ischemic stroke. Neuromol Med 2006, 8:353-360.

56. Wang XL, Sim AS, Badenhop RF, McCredie RM, Wilcken DE: A smokingdependent risk of coronary artery disease associated with a polymorphism of the endothelial nitric oxide synthase gene. Nat Med 1996, 2:41-45.

57. Howard TD, Giles WH, XU J, Wozniak MA, Malarcher AM, Lange LA, Macko RF, Basehore MJ, Meyers DA, Cole JW, Kittner SJ: Promoter polymorphisms in the nitric oxide synthase 3 gene are associated with ischemic stroke susceptibility in young black women. Stroke 2005, 36:1848-1851.

58. Szolnoki Z, Havasi V, Bene J, Komlósi K, Szöke D, Somogyvári F, Kondacs A, Szabó M, Fodor L, Bodor A, Gáti I, Wittman I, Melegh B: Endothelial nitric oxide synthase gene interactions and the risk of ischaemic stroke. Acta Neurol Scand 2005, 111:29-33.

59. Margaglione M, D'Andrea G, Giuliani N, Brancaccio V, De LD, Grandone E, De S, V, Tonali PA, Di MG: Inherited prothrombotic conditions and premature ischemic stroke: sex difference in the association with factor V Leiden. Arterioscler Thromb Vasc Biol 1999, 19:1751-1756.
60. Szolnoki Z, Somogyvari F, Szabo M, Kondacs A, Fodor L, Melegh B: [Interactions between the MTHFR C677T and MTHFR A1298C mutations in ischaemic stroke]. Ideggyogy Sz 2006, 59:107-112.

61. Szolnoki Z, Maasz A, Magyari L, Horvatovich K, Farago B, Somogyvari F, Kondacs A, Szabo M, Bodor A, Hadarits F, Melegh B: The combination of homozygous MTHFR 677T and angiotensin II type-1 receptor $1166 \mathrm{C}$ variants confers the risk of small-vessel-associated ischemic stroke. J Mol Neurosci 2007, 31:201-207.

62. Utermann G, Hees M, Steinmetz A: Polymorphism of apolipoprotein E and occurrence of dysbetalipoproteinaemia in man. Nature 1977, 269:604-607.

63. Eto M, Watanabe K, Ishii K: Reciprocal effects of apolipoprotein E alleles (epsilon 2 and epsilon 4) on plasma lipid levels in normolipidemic subjects. Clin Genet 1986, 29:477-484.

64. Margaglione M, Seripa D, Gravina C, Grandone E, Vecchione G, Cappucci G, Merla G, Papa S, Postiglione A, Di Minno G, Fazio VM: Prevalence of apolipoprotein E alleles in healthy subjects and survivors of ischemic stroke: an Italian Case-Control Study. Stroke 1998, 29:399-403.

65. Catto AJ, McCormack L, Mansfield MW, Carter AM, Bamford JM, Robinson P Grant PJ: Apolipoprotein E polymorphism in cerebrovascular disease. Acta Neuro/ Scand 2000, 101:399-404

66. Kathiresan S, Melander O, Guiducci C, Surti A, Burtt NP, Rieder MJ, Cooper GM, Roos C, Voight BF, Havulinna AS, Wahlstrand B, Hedner T, Corella D, Tai ES, Ordovas JM, Berglund G, Vartiainen E, Jousilahti P, Hedblad B, Taskinen MR, Newton-Cheh C, Salomaa V, Peltonen L, Groop L, Altshuler DM, OrhoMelander M: Six new loci associated with blood low-density lipoprotein cholesterol, high-density lipoprotein cholesterol or triglycerides in humans. Nat Genet 2008, 40:189-197.

67. Hokanson JE, Austin MA: Plasma triglyceride level is a risk factor for cardiovascular disease independent of high-density lipoprotein cholesterol level: a meta-analysis of population-based prospective studies. J Cardiovasc Risk 1996, 3:213-219.

68. Malloy MJ, Kane JP: A risk factor for atherosclerosis: triglyceride-rich lipoproteins. Adv Intern Med 2001, 47:111-136.

69. Hopkins PN, Wu LL, Hunt SC, Brinton EA: Plasma triglycerides and type III hyperlipidemia are independently associated with premature familial coronary artery disease. J Am Coll Cardiol 2005, 45:1003-1012.

70. Willer CJ, Sanna S, Jackson AU, Scuteri A, Bonnycastle LL, Clarke R, Heath SC, Timpson NJ, Najjar SS, Stringham HM, Strait J, Duren WL, Maschio A, Busonero F, Mulas A, Albai G, Swift AJ, Morken MA, Narisu N, Bennett D, Parish S, Shen H, Galan P, Meneton P, Hercberg S, Zelenika D, Chen WM, Li Y, Scott LJ, Scheet $P A$, et al:: Newly identified loci that influence lipid concentrations and risk of coronary artery disease. Nat Genet 2008, 40:161-169.

71. Groenendijk M, Cantor RM, De Bruin TW, Dallinga-Thie GM: The apoAI-CIII-AIV gene cluster. Atherosclerosis 2001, 157:1-11.

72. Jong MC, Hofker MH, Havekes LM: Role of ApoCs in lipoprotein metabolism: functional differences between ApoC1, ApoC2, and ApoC3. Arterioscler Thromb Vasc Biol 1999, 19:472-484.

73. Talmud PJ, Hawe E, Martin S, Olivier M, Miller GJ, Rubin EM, Pennacchio LA, Humphries SE: Relative contribution of variation within the APOC3/A4/A5 gene cluster in determining plasma triglycerides. Hum Mol Genet 2002, 11:3039-3046.

74. Waterworth DM, Hubacek JA, Pitha J, Kovar J, Poledne R, Humphries SE, Talmud PJ: Plasma levels of remnant particles are determined in part by variation in the APOC3 gene insulin response element and the APOCI-APOE cluster. J Lipid Res 2000, 41:1103-1109.

75. Waterworth DM, Talmud PJ, Bujac SR, Fisher RM, Miller GJ, Humphries SE: Contribution of apolipoprotein C-III gene variants to determination of triglyceride levels and interaction with smoking in middle-aged men. Arterioscler Thromb Vasc Biol 2000, 20:2663-2669.

76. Aalto-Setälä K, Palomäki H, Miettinen H, Vuorio A, Kuusi T, Raininko R, Salonen $O$, Kaste M, Kontula K: Genetic risk factors and ischaemic cerebrovascular disease: role of common variation of the genes encoding apolipoproteins and angiotensin-converting enzyme. Ann Med 1998, 30:224-233.

77. Pennacchio LA, Olivier M, Hubacek JA, Cohen JC, Cox DR, Fruchart JC, Krauss RM, Rubin EM: An apolipoprotein influencing triglycerides in humans and mice revealed by comparative sequencing. Science 2001, 294:169-173.

78. Weinberg RB, Cook VR, Beckstead JA, Martin DD, Gallagher JW, Shelness GS, Ryan RO: Structure and interfacial properties of human apolipoprotein A-V. J Biol Chem 2003, 278:34438-34444.

79. Merkel M, Heeren J: Give me A5 for lipoprotein hydrolysis! J Clin Invest 2005, 115:2694-2696. 
80. Merkel M, Loeffler B, Kluger M, Fabig N, Geppert G, Pennacchio LA, Laatsch A, Heeren J: Apolipoprotein AV accelerates plasma hydrolysis of triglyceriderich lipoproteins by interaction with proteoglycan-bound lipoprotein lipase. J Biol Chem 2005, 280:21553-21560.

81. Ruiz-Narvaez EA, Yang Y, Nakanishi Y, Kirchdorfer J, Campos H: APOC3/A5 haplotypes, lipid levels, and risk of myocardial infarction in the Central Valley of Costa Rica. J Lipid Res 2005, 46:2605-2613.

82. Hubacek JA: Apolipoprotein A5 and triglyceridemia. Focus on the effects of the common variants. Clin Chem Lab Med 2005, 43:897-902.

83. Talmud PJ: Rare APOA5 mutations - clinical consequences, metabolic and functional effects: an ENID review. Atherosclerosis 2007, 194:287-292.

84. Pennacchio LA, Rubin EM: Apolipoprotein A5, a newly identified gene that affects plasma triglyceride levels in humans and mice. Arterioscler Thromb Vasc Biol 2003, 23:529-534.

85. Pennacchio LA, Olivier M, Hubacek JA, Krauss RM, Rubin EM, Cohen JC: Two independent apolipoprotein A5 haplotypes influence human plasma triglyceride levels. Hum Mol Genet 2002, 11:3031-3038.

86. Havasi V, Szolnoki Z, Talián G, Bene J, Komlósi K, Maász A, Somogyvári F, Kondacs A, Szabó M, Fodor L, Bodor A, Melegh B: Apolipoprotein A5 gene promoter region T-1131C polymorphism associates with elevated circulating triglyceride levels and confers susceptibility for development of ischemic stroke. J Mol Neurosci 2006, 29:177-183.

87. Maasz A, Kisfali P, Jaromi L, Horvatovich K, Szolnoki Z, Csongei V, Safrany E, Sipeky C, Hadarits F, Melegh B: Apolipoprotein A5 gene IVS3+G476A allelic variant confers susceptibility for development of ischemic stroke. Circ J 2008, 72:1065-1070.

88. Maasz A, Kisfali P, Szolnoki Z, Hadarits F, Melegh B: Apolipoprotein A5 gene C56G variant confers risk for the development of large-vessel associated ischemic stroke. J Neuro/ 2008, 255:649-654.

89. Kisfali P, Mohás M, Maász A, Polgár N, Hadarits F, Markó L, Brasnyó P, Horvatovich K, Oroszlán T, Bagosi Z, Bujtor Z, Gasztonyi B, Rinfel J, Wittmann I, Melegh B: Haplotype analysis of the apolipoprotein A5 gene in patients with the metabolic syndrome. Nutr Metab Cardiovasc Dis 2009, 20:505-511.

90. Kisfali P, Mohás M, Maasz A, Hadarits F, Markó L, Horvatovich K, Oroszlán T, Bagosi Z, Bujtor Z, Gasztonyi B, Wittmann I, Melegh B: Apolipoprotein A5 IVS3+476A allelic variant associates with increased trigliceride levels and confers risk for development of metabolic syndrome in Hungarians. Circ $J$ 2008, 72:40-43.

91. Maász A, Kisfali P, Horvatovich K, Mohás M, Markó L, Csöngei V, Faragó B, Járomi L, Magyari L, Sáfrány E, Sipeky C, Wittmann I, Melegh B: Apolipoprotein A5 T-1131C variant confers risk for metabolic syndrome. Pathol Oncol Res 2007, 13:243-247.

92. Havel RJ, Fielding CJ, Olivecrona T, Shore VG, Fielding PE, Egelrud T: Cofactor activity of protein components of human very low density lipoproteins in the hydrolysis of triglycerides by lipoproteins lipase from different sources. Biochemistry 1973, 12:1828-1833.

93. Merkel M, Eckel RH, Goldberg IJ: Lipoprotein lipase: genetics, lipid uptake, and regulation. J Lipid Res 2002, 43:1997-2006

94. Huang P, Kostulas K, Huang WX, Crisby M, Kostulas V, Hillert J: Lipoprotein lipase gene polymorphisms in ischaemic stroke and carotid stenosis. Eur J Clin Invest 1997, 27:740-742.

95. Wittrup HH, Nordestgaard BG, Sillesen H, Schnohr P, Tybjaerg-Hansen A: A common mutation in lipoprotein lipase confers a 2-fold increase in risk of ischemic cerebrovascular disease in women but not in men. Circulation 2000, 101:2393-2397.

96. Gretarsdottir S, Thorleifsson G, Reynisdottir ST, Manolescu A, Jonsdottir S, Jonsdottir T, Gudmundsdottir T, Bjarnadottir SM, Einarsson OB, Gudjonsdottir HM, Hawkins M, Gudmundsson G, Gudmundsdottir H, Andrason $H_{\text {, }}$ Gudmundsdottir AS, Sigurdardottir M, Chou TT, Nahmias J, Goss S, Sveinbjörnsdottir S, Valdimarsson EM, Jakobsson F, Agnarsson U, Gudnason V, Thorgeirsson G, Fingerle J, Gurney M, Gudbjartsson D, Frigge ML, Kong A, et al:: The gene encoding phosphodiesterase $4 \mathrm{D}$ confers risk of ischemic stroke. Nat Genet 2003, 35:131-138.

97. Meschia JF, Brott TG, Brown RD Jr, Crook R, Worrall BB, Kissela B, Brown WM, Rich SS, Case LD, Evans EW, Hague S, Singleton A, Hardy J; SWISS Study Group; ISGS Study Group; MSGD Study Group: Phosphodiesterase 4D and 5-lipoxygenase activating protein in ischemic stroke. Ann Neurol 2005, 58:351-361.

98. Zee RY, Brophy VH, Cheng S, Hegener HH, Erlich HA, Ridker PM: Polymorphisms of the phosphodiesterase 4D, cAMP-specific (PDE4D) gene and risk of ischemic stroke: a prospective, nested case-control evaluation. Stroke 2006, 37:2012-2017.
99. Matsushita T, Kubo M, Yonemoto K, Ninomiya T, Ashikawa K, Liang B, Hata J, Doi Y, Kitazono T, Ibayashi S, lida M, Kiyohara Y, Nakamura Y: Lack of association between variations of PDE4D and ischemic stroke in the Japanese population. Stroke 2009, 40:1245-1251.

100. Lohmussaar E, Gschwendtner A, Mueller JC, Org T, Wichmann E, Hamann G, Meitinger T, Dichgans M: ALOX5AP gene and the PDE4D gene in a central European population of stroke patients. Stroke 2005, 36:731-736.

101. Helgadottir A, Manolescu A, Thorleifsson G, Gretarsdottir S, Jonsdottir H, Thorsteinsdottir U, Samani NJ, Gudmundsson G, Grant SF, Thorgeirsson G, Sveinbjornsdottir S, Valdimarsson EM, Matthiasson SE, Johannsson H, Gudmundsdottir O, Gurney ME, Sainz J, Thorhallsdottir M, Andresdottir M, Frigge ML, Topol EJ, Kong A, Gudnason V, Hakonarson H, Gulcher JR, Stefansson $\mathrm{K}$ : The gene encoding 5-lipoxygenase activating protein confers risk of myocardial infarction and stroke. Nat Genet 2004, 36:233-239.

102. Helgadottir A, Gretarsdottir S, St Clair D, Manolescu A, Cheung J, Thorleifsson G, Pasdar A, Grant SF, Whalley LJ, Hakonarson H, Thorsteinsdottir U, Kong A, Gulcher J, Stefansson K, MacLeod MJ: Association between the gene encoding 5-lipoxygenase-activating protein and stroke replicated in a Scottish population. Am J Hum Genet 2005, 76:505-509.

103. Zee RY, Cheng S, Hegener HH, Erlich HA, Ridker PM: Genetic variants of arachidonate 5-lipoxygenase-activating protein, and risk of incident myocardial infarction and ischemic stroke: a nested case-control approach. Stroke 2006, 37:2007-2011.

104. Járomi L, Csöngei V, Polgár N, Szolnoki Z, Maász A, Horvatovich K, Faragó B, Sipeky C, Sáfrány E, Magyari L, Kisfali P, Mohás M, Janicsek I, Lakner L, Melegh B: Functional variants of glucokinase regulatory protein and apolipoprotein A5 genes in ischemic stroke. J Mol Neurosci 2010, 41:121-128.

105. Polgar N, Jaromi L, Csongei V, Maasz A, Sipeky C, Safrany E, Szabo M, Melegh B: Triglyceride level modifying functional variants of GALTN2 and MLXIPL in patients with ischaemic stroke. Eur J Neuro/ 2010, 17:1033-1039.

106. Matarín M, Brown WM, Scholz S, Simón-Sánchez J, Fung HC, Hernandez D, Gibbs JR, De Vrieze FW, Crews C, Britton A, Langefeld CD, Brott TG, Brown RD Jr, Worrall BB, Frankel M, Silliman S, Case LD, Singleton A, Hardy JA, Rich SS, Meschia JF: A genome-wide genotyping study in patients with ischaemic stroke: initial analysis and data release. Lancet Neurol 2007, 6:414-420.

107. Gretarsdottir S, Thorleifsson G, Manolescu A, Styrkarsdottir U, Helgadottir A, Gschwendtner A, Kostulas K, Kuhlenbäumer G, Bevan S, Jonsdottir T, Bjarnason H, Saemundsdottir J, Palsson S, Arnar DO, Holm H, Thorgeirsson G, Valdimarsson EM, Sveinbjörnsdottir S, Gieger C, Berger K, Wichmann HE, Hillert J, Markus H, Gulcher JR, Ringelstein EB, Kong A, Dichgans M, Gudbjartsson DF, Thorsteinsdottir U, Stefansson K: Risk variants for atrial fibrillation on chromosome $4 \mathrm{q} 25$ associate with ischemic stroke. Ann Neurol 2008, 64:402-409.

108. Sowden JC: Molecular and developmental mechanisms of anterior segment dysgenesis. Eye (Lond) 2007, 21:1310-1318.

109. Strungaru MH, Dinu I, Walter MA: Genotype-phenotype correlations in Axenfeld-Rieger malformation and glaucoma patients with FOXC1 and PITX2 mutations. Invest Ophthalmol Vis Sci 2007, 48:228-237.

110. Yamada Y, Fuku N, Tanaka M, Aoyagi Y, Sawabe M, Metoki N, Yoshida H, Satoh K, Kato K, Watanabe S, Nozawa Y, Hasegawa A, Kojima T: Identification of CELSR1 as a susceptibility gene for ischemic stroke in Japanese individuals by a genome-wide association study. Atherosclerosis 2009, 207:144-149.

111. Ikram MA, Seshadri S, Bis JC, Fornage M, DeStefano AL, Aulchenko YS, Debette S, Lumley T, Folsom AR, van den Herik EG, Bos MJ, Beiser A, Cushman M, Launer L, Shahar E, Struchalin M, Du Y, Glazer NL, Rosamond WD, Rivadeneira F, Kelly-Hayes M, Lopez OL, Coresh J, Hofman A, DeCarli C, Heckbert SR, Koudstaal PJ, Yang Q, Smith NL, Kase CS: Genomewide association studies of stroke. N Engl J Med 2009, 360:1718-1728.

112. Illig T, Gieger C, Zhai G, Römisch-MargI W, Wang-Sattler R, Prehn C, Altmaier E, Kastenmüller G, Kato BS, Mewes HW, Meitinger T, de Angelis MH, Kronenberg F, Soranzo N, Wichmann HE, Spector TD, Adamski J, Suhre K: A genome-wide perspective of genetic variation in human metabolism. Nat Genet 2010, 42:137-141.

113. Grosse SD, Khoury MJ: What is the clinical utility of genetic testing? Genet Med 2006, 8:448-450.

114. Kaye J: The regulation of direct-to-consumer genetic tests. Hum Mol Genet 2008, 17:R180-R183.

115. Schickedanz AD, Herdman RC: Direct-to-consumer genetic testing: the need to get retail genomics right. Clin Pharmacol Ther 2009, 86:17-20.

116. Patch C, Sequeiros J, Cornel MC: Direct to consumer genetic tests. Eur J Hum Genet 2009, 17:1111. 
117. Patch C, Sequeiros J, Cornel MC: Genetic horoscopes: is it all in the genes? Points for regulatory control of direct-to-consumer genetic testing. Eur J Hum Genet 2009, 17:857-859.

118. Gurwitz D, Bregman-Eschet Y: Personal genomics services: whose genomes? Eur J Hum Genet 2009, 17:883-889. doi:10.1186/gm185

Cite this article as: Maasz A, Melegh B: Three periods of one and a half decade of ischemic stroke susceptibility gene research: lessons we have learned. Genome Medicine 2010, 2:64. 